\title{
Explicating Correlates of Juvenile Offender Detention Length: The Impact of Race, Mental Health Difficulties, Maltreatment, Offense Type, and Court Dispositions
}

\author{
Christopher A. Mallett \\ Cleveland State University, c.a.mallett@csuohio.edu \\ Patricia A. Stoddard Dare \\ Cleveland State University, p.stoddarddare@csuohio.edu \\ Mamadou M. Seck \\ Cleveland State University, m.seck@csuohio.edu
}

Follow this and additional works at: https://engagedscholarship.csuohio.edu/clsowo_facpub

Part of the Criminal Law Commons, Juvenile Law Commons, Social Control, Law, Crime, and Deviance Commons, and the Social Work Commons

How does access to this work benefit you? Let us know!

\section{Publisher's Statement}

(c) 2011 Sage Publications

\section{Recommended Citation}

Mallett, Christopher A.; Stoddard Dare, Patricia A.; and Seck, Mamadou M., "Explicating Correlates of Juvenile Offender Detention Length: The Impact of Race, Mental Health Difficulties, Maltreatment, Offense Type, and Court Dispositions" (2011). Social Work Faculty Publications. 21.

https://engagedscholarship.csuohio.edu/clsowo_facpub/21

This Article is brought to you for free and open access by the School of Social Work at EngagedScholarship@CSU. It has been accepted for inclusion in Social Work Faculty Publications by an authorized administrator of EngagedScholarship@CSU. For more information, please contact library.es@csuohio.edu. 


\title{
Explicating Correlates of Juvenile Offender Detention Length:The Impact of Race, Mental Health Difficulties, Maltreatment, Offense Type, and Court Dispositions
}

\author{
Christopher A. Mallett, Patricia Stoddard-Dare \\ and Mamadou M. Seck
}

\begin{abstract}
Detention and confinement are widely acknowledged juvenile justice system problems which require further research to understand the explanations for these outcomes. Existing juvenile court, mental health, and child welfare histories were used to explicate factors which predict detention length in this random sample of 342 youth from one large, urban Midwestern county in the United States. Data from this sample revealed eight variables which predict detention length. Legitimate predictors of longer detention length such as committing a personal crime or violating a court order were nearly as likely in this sample to predict detention length as other extra-legal predictors such as race, court disposition for mental health problems, child welfare involvement, and child physical abuse victimization. Many of the factors that increase duration of detention are actually disadvantages that these youth endure; therefore preventative and intervention measures are in order.
\end{abstract}

\section{Keywords}

child maltreatment, detention, juvenile, mental health, minority race

\section{Introduction}

Delinquency is a problem among youth in the United States. Of the millions of youth arrests annually, 1.7 million of these offenders are eventually adjudicated delinquent (with legal oversight by the juvenile court), and an additional 550,000 of these offenders are placed under direct probation supervision (National Council on Crime and Delinquency, 2007; Sickmund, 2009). Although there are many sanctions used by the juvenile courts to punish, deter, or reform youth, secure detention placement continues to be a commonly used intervention. Indeed, 350,000 juvenile offenders were placed into detention in 2006 
for either pre-trial holding or post-trial sentencing (Sickmund, 2006). These detention stays have increasingly been found to decrease public safety because they look to be causal influences on later youth re-offending and recidivism (Justice Policy Institute, 2009; Soler, Shoenberg, and Schindler, 2009).

Although juvenile court policies and procedures heavily impact detention placement decisions, other variables that impact detention arguably should pertain to legal rather than extra-legal factors. In the following sections, literature will be reviewed which identifies first the court offense types (legal variable) and then extra-legal variables (race, mental health, substance abuse, maltreatment) as they relate to delinquency and detention. Next, what little is known about these variables and detention length will be presented. The literature review will conclude with discussion of some important gaps in previous research and justification for the current study.

\section{Court Offense Types Related to Delinquency and Detention}

One important legal factor that has been investigated is the relationship between juvenile offender offense type and detention placement. Although research is somewhat limited concerning this link between juvenile offense types (categorized commonly as personal, property, drug, status/public order offenses, and court order violations) and detention or incarceration placement, some important information has been published. In one large urban county studied, among numerous variables predicted, probation (court order) violations were identified as predictive of offender pre-trial detention placement, though other offense categories were only measured as misdemeanors or felonies (O'Neill, 2002). Status offense convictions have also been found to be predictive of recidivism in other juvenile offender populations (Myner, Santman, Cappelletty, and Perlmutter, 1998), as well as drug offenses and personal offenses (Robertson, Dill, Husain, and Undesser, 2004). Investigations of the impact offense type have on juvenile offender outcomes is important, considering recent trends. From 1998 to 2007, while juvenile offender delinquency rates have trended down slightly (7\%), person offenses (up 1\%) and drug offenses (down 2\%) have generally followed this trend; however, public order offenses (up 13\%) and property offenses (down 24\%) have changed significantly (Knoll and Sickmund, 2010). Knowing more about the association between different offense type and detention may be important for juvenile court personnel decision-making. In addition to offense type and its relation to delinquency and detention, there are many extralegal variables.

\section{Extra Legal Variables Related to Delinquency and Detention}

Troubled youth involved with the juvenile justice system many times have significant individual and family struggles that are pathways toward delinquent behaviors and activities. These difficulties include, but are not limited to, family violence, child abuse and neglect, poverty, academic difficulties, and youth and parent mental health and substance abuse problems. These traumas and problems are very commonly found within juvenile court populations, for a majority of these youth have experienced one, and often more 
than one, difficulty. While many youth with these experiences will not come under juvenile court supervision, those that do are already at a significant disadvantage - they have family difficulties, maltreatment histories, and/or mental health problems, and are then adjudicated delinquent and come under juvenile court supervision. This means that of the 1.7 million youth adjudicated delinquent annually in the United States, a disproportionate number have these histories and difficulties; and - a related problem - a disproportionate number of these youth are minorities (National Council on Crime and Delinquency, 2007; Sickmund, 2009).

To date, no single risk factor has been identified as a causal link to juvenile delinquency and subsequent detention or confinement (Howing, Wodarski, Kurtz, Gaudin, and Herbst, 1990; Maas, Herrenkohl, and Sousa, 2008; Preski and Shelton, 2001; Stouthamer-Loeber, Wei, Homish, and Loeber, 2002; Turner, Hartman, Exum, and Cullen, 2007; Widom and Maxfield, 2001). There exist multiple risk factors in children and their backgrounds including deficits in family, school, peers, and neighborhoods (Hay, Fortson, Hollist, Altheimer, and Schaible, 2006; Hawkins et al., 1998; Heilbrum, Goldstein, and Redding, 2005; Howell, 2003; Loeber and Dishion, 1983; Loeber and Farrington, 2001; Mears and Aron, 2003; Strouthamer-Loeber et al., 2002). These risk factors tend to be cumulative and to have interactive effects, making prediction difficult (Ford, Chapman, Hawke, and Albert, 2007; Green, Gesten, Greenwald, and Salcedo, 2008; Lemmon, 2006). In the following sections important information about the relationship between three extra-legal variables (race, mental health and substance abuse problems, and child maltreatment) and delinquency and detention will be described.

\section{Minority Race}

Minority youth, especially African-Americans, are found disproportionately at the point of arrest, detainment pending investigation, juvenile court referral case petitioning, and secure confinement (Puzzanchera, Adams, and Snyder, 2008). Minority youth are also less likely to be diverted from the juvenile courts when compared to non-minority youth, and consequently more likely to come under court probation supervision (National Council on Crime and Delinquency, 2007; Puzzanchera et al., 2008).

In particular, an African-American youth is six times more likely to be incarcerated (jails and detention facilities) compared to white youth, and held on average 61 days longer (Mauer and King, 2007; National Council on Crime and Delinquency, 2007). These detention disparities, both pre- and post-adjudication, are found across all offense categories person, property, drug, and public order - though they are more pronounced in drug offense cases (National Council on Crime and Delinquency, 2007). In addition, it was found that Hispanic youth were more likely than Caucasian youth to be detained for a new offense, while Caucasian youth were more likely to be detained for non-criminal (status) offenses (Hodge and Greenleaf, 2005). Most challenging is that minority youth are more likely to be incarcerated than non-minority youth for the same types of offenses (Green, Hoyt, Schiraldi, Smith, and Ziedenberg 2001; National Council on Crime and Delinquency, 2007; Poe-Yamagata and Jones, 2000; Shelton, Neelum, and Augarten, 2008). 


\section{Mental health and substance abuse problems}

Mental health difficulties are linked to later youth offending behavior and delinquency adjudication, though it is not clear if this link is direct or if these difficulties lead to other risk factors or poor decision-making (Grisso, 2008; Heilbrum, Goldstein, and Redding, 2005; Mallett, Stoddard-Dare, and Seck, 2009). Early childhood aggressive behaviors have been found predictive of later delinquent activities (Kashani, Jones, Bumby, and Thomas, 1999; Tremblay and LeMarquand, 2001). Attention and hyperactivity problems look to be linked to later high-risk taking and more violent offending behavior (Hawkins et al., 1998; Kashani et al., 1999). The direct link is more clearly established and recognized when looking at those youth who are eventually juvenile court supervised, for a majority of these juvenile offenders have at least one diagnosed mental health disorder, many of these severe (Grisso, 2008; Shufelt and Cocozza, 2006). Specifically, childhood depression and attention deficit-hyperactivity disorder have been found to be linked to later delinquency, evidenced through physical aggression and stealing behaviors (Loeber and Keenan, 1994; Moffitt and Scott, 2008; Takeda, 2000). In addition, a large number of these juvenile offenders have a mental health disorder and a substance abuse disorder, a co-morbidity problem (Teplin, Abram, McClelland, Dulcan, and Mericle, 2002; Teplin, Abram, McClelland, Mericle, Dulcan, and Washburn, 2006).

Adolescent mental health and delinquent populations were found to have risk factors for detention or incarceration that included being African-American or Hispanic, in middle school, having a diagnosis of alcohol problems or conduct disorder, reported use and abuse of substances, and receiving prior mental health services (Scott, Snowden, and Libby, 2002; Watts and Wright, 1990). Earlier studies found an increased risk of juvenile justice system detainment for minorities, drug use, and public mental health insurance (Mason and Gibbs, 1992; Westendorp, Brink, Roberson, and Ortiz, 1986). Youth who received prior mental health system services who were later juvenile court involved were more at risk, when compared to non-juvenile court involved peers, for drug and/or alcohol abuse, conduct disorder, and to have been physical abused (Evans and Vander Stoep, 1997; Rosenblatt, Rosenblatt, and Biggs, 2000). These two populations - youth with emotional disturbances and youth involved in the juvenile justice system - vary little across service delivery; in other words, are often the same or have similar youth needs (Melton and Pagliocca, 1992; Teplin et al., 2002).

\section{Childhood maltreatment}

A history of maltreatment is consistently found within delinquent youth populations (Lemmon, 1999; Smith and Thornberry, 1995; Wiebush, McNulty, and Le, 2000). However, maltreatment's specific impact, type, or duration is unclear. One study identified that maltreatment led to an almost two times greater chance of juvenile arrest, although the pattern of risk varied by gender, race, and maltreatment type (Maxfield and Widom, 1996). Some studies have identified victims of physical abuse and neglect to have elevated risk, but not victims of sexual abuse (Egeland, Yates, Appleyard, and van Dulmen, 2002; Fagan, 2005; Herrenkohl, Egolf, and Herrenkohl, 1997; Maxfield and Widom, 1996; Mersky and 
Reynolds, 2007; Spilsbury et al., 2007; Widom and Maxfield, 2001). Narrower definitions of delinquency have been used in finding that maltreatment type did not have a significant impact on delinquency (Maxfield and Widom, 1996; Zingraff, Leiter, Johnson, and Myers, 1993). Significant relationships have been found between maltreatment severity and moderate to violent delinquency (Maxfield and Widom, 1996; Smith and Thornberry, 1995). Also, increased and repeated exposure to childhood maltreatment led to higher delinquency risks, continuation, and severity (Currie and Tekin, 2006; Lemmon, 1999; 2006; Smith and Thornberry, 1995; Thornberry, Ireland, and Smith, 2001).

\section{Detention length}

What is known is that delinquency among youth is a pressing issue of concern for multiple stakeholders, and legal and extra legal factors have been identified as impacting delinquency and detention placement. Few studies have looked at incarceration length and subsequent juvenile offender outcomes, and the ones to date have all reviewed either long-term incarceration facilities (juvenile jails) or residential/treatment facilities. Overall, the findings on incarceration length are inconclusive, with results from these studies showing a range of outcomes. Some reviews have found limited benefit to public safety and youth rehabilitation for residential placement, dependent on the program type and duration (Lipsey and Wilson, 1998; Lipsey, Wilson, and Cothern, 2000). Other reviews have found that placement has no impact on youth re-arrest or recidivism rates (Loughran et al., 2009; Winokur, Smith, Bontrager, and Blankenship, 2008). Additional reviews have found placement to be an increased risk for youth offender recidivism (Budeiri, 1999; Myner, Santman, Cappalletty, and Perlmutter, 1998). To restate, few prior studies have looked at only juvenile offender detention length and subsequent outcomes, though the consensus is that future research should identify who is most at risk for longer incarcerations and what these incarceration effects have on the youth (Winokur et al., 2008).

However, the impact of detention placement on youth has been more extensively reviewed, finding more harm than good. Being placed into detention makes it more likely that the youth will continue to engage in delinquent behavior, and may actually increase the odds that they commit additional crimes (Gatti, Tremblay, and Vitaro, 2009; Holman and Ziedenberg, 2006; Torres and Ooyen, 2002). Considering that of the 450,000 juvenile offenders held in secure facilities annually in the United States, 350,000 of these are held in detention centers (and not incarceration/jail facilities), a focus on detention placement and detention length is in order (Davis, Tsukida, Marchionna, and Krisberg, 2008; Holman and Ziedenberg, 2006; Sickmund, 2006; Sickmund, Sladky, and Wang, 2004).

\section{Gaps in previous research and justification for the current study}

Although previous literature has identified a link between certain legal and extra-legal variables and delinquency and detention placement, literature is very limited regarding length of detainment placement. As discussed, incarceration length impact studies are inconclusive to date, while detention length impact studies are nonexistent (Loughran 
et al., 2009; Winokur et al., 2008). In this study, the link between detention placement length and theoretically relevant legal and extra legal variables will be explored. Literature to date links these (and other) factors to initial detention placement, but there are two epistemological benefits to examining the link to detention length. One, increasing detention length prediction knowledge can better inform the juvenile court personnel's decision making; and two, there is very limited knowledge of these risk factors' impact on length of juvenile offender detention. For if detention is known to have outcomes that do not support community safety and juvenile offender rehabilitative public policy goals, then minimizing this would be of significant importance (Benda and Tollet, 1999; Grisso, 2008; Justice Policy Institute, 2009; Loughran et al., 2009). In fact, the reformation of juvenile detention continues to occur in many U.S. counties and states, with a focus on minimizing both the juvenile offenders' placement and, if placed, minimizing length of time held in detention (Annie E. Casey Foundation, 2010). Understanding factors which predict detention length can assist stakeholders to tailor prevention and intervention efforts aimed to reduce detention length when appropriate.

\section{Methods}

\section{Design/research question}

This retrospective study utilized adjudicated delinquent youth (and families) tracked over a three-year time frame. Confidential court and probation supervision records were provided by one Midwest state's juvenile court in the United States to investigate what factors impact length of time offenders spend in detention. The choice of variables utilized in this study is supported because of the known relationship between these variables and placement in detention, and the potential negative and harmful impact detention has been found to have on these youths (Currie and Tekin, 2006; Hodge and Greenleaf, 2005; Loughran et al., 2009; O'Neill, 2002; Scott et al., 2002). Specifically, this study evaluated to what extent race, gender, age at first delinquency adjudication, number of siblings, prior mental health history, child abuse and neglect history, substance abuse history, type of offense, and juvenile court dispositions explain the length of time a probationer spends in detention.

\section{Sampling}

This study's sampling frame included the juvenile justice populations from one large, urban county in the United States (Stahl et al., 2007). This county juvenile court supervises the largest number of juvenile offenders compared to other county juvenile courts in the state, and detained 2586 of these offenders in 2008. This county juvenile court has a demonstrated disproportionate minority contact concern at four processing stages - arrests, referral to juvenile court, secure detention, and state facility incarceration. This county juvenile court provided three years of data (2006, 2007, and 2008). The county juvenile probation and offender population averaged 2300 youth for each of these years. 
An a priori analysis was conducted to determine the appropriate sample size to achieve a five per cent margin of error and 95 per cent confidence interval, assuming a population proportion of 50 per cent (Royse, Thyer, Padgett, and Logan, 2006). Given a combined population size of 6900 over the study period, the appropriate sample size was calculated to be $N=360$ (Royse, Thyer, Padgett, and Logan, 2006: 224). A simple random sample (using an electronic random number table) was drawn for each population year of the county's juvenile probation population - youth who had been adjudicated delinquent during that calendar year and chosen for the study did not include youth transferred to criminal (adult) court. A total of 342 unique (not duplicated) youth were included in this study sample: $2006=100 ; 2007=137 ; 2008=105$.

Of those 342 youth, they were primarily African-American (72\%) and male (74\%). They were, on average, 15.4 years of age, and they were 14.8 years of age, on average, when they had their first delinquency adjudication. They came from households where, on average, they had 2.5 siblings. These youth spent an average of 21 days in detention (standard deviation of 52 days); 19 per cent recidivated to detention placement. These youth had various offenses leading to delinquency adjudication: property crimes $(55.1 \%)$; personal crimes (61.6\%); drug crimes (22.1\%); status offenses (32.8\%); and court order violation (33.7\%). Eight per cent of the youths had been a previous victim of physical abuse and four per cent had suffered sexual abuse. Over half of these youth (50.6\%) had some sort of neglect or suffered parental substance abuse. However, three-quarters of the youth (74.6\%) had not had any issues or problems with substance use themselves, although a third $(30.5 \%)$ did have problems with emotional or behavioral issues. In the past, one in four of these youth had contact with the mental health system. Almost sixty per cent (59.8\%) of the youth had a court disposition to a mental health treatment/service area, while few $(5.6 \%)$ had a disposition from the court for shelter care or to a public children services agency $(2.3 \%)$.

\section{Data collection}

The county juvenile court provided copies of case files for the youth and families involved in this study. These files included probation supervision case files, juvenile court histories, mental health assessments, and child welfare histories. Data entered was evaluated for proper coding. Inter-coder reliability was high (.96) - with evaluations occurring at the end of each file input.

\section{Measurement}

A total of 31 variables, all measured dichotomously (yes/no) unless otherwise noted, were measured and evaluated for possible inclusion in this study. Demographic variables such as current age (on January 1 of data year, measured in years), gender (male/female), number of siblings (continuous), and race $(0=$ Not African-American, $1=$ AfricanAmerican) were derived from existing case records. Prior mental health counseling, prior hospitalization in a psychiatric institution, and prior history of psychiatric medication were all measured using official mental health case records dated prior to the juvenile's 
first delinquency adjudication, and prepared by a licensed mental health provider. Prior suicide attempt was measured through self report notation in the juvenile's case file and/ or through prior mental health case records. Information regarding history of sexual abuse, physical abuse, or neglect, and history of child welfare system involvement, were derived from existing child welfare case records. Only cases of children who experienced substantiated sexual abuse, physical abuse, and/or neglect as defined by state law were counted as 'yes'. Lifetime/current maternal and paternal substance abuse/dependence status was assessed by a professional psychologist or psychiatrist utilizing the Diagnostic and Statistical Manual of Mental Disorders-IV (APA, 2000) (the DSM-IV is the required psychiatry nosology system used in the United States, while the International Classification of Diseases is used in most other countries) and was derived from child welfare records, or by notion made by probation officer documentation in the juvenile's case file. Information regarding court dispositions for counseling, mental health evaluation, and drug screening, as well as referrals to shelter care and public children's service agencies were all derived from probation and supervision case files. In the cases of youth with multiple offenses over time, any court disposition for these services was counted. Youth history of current or lifetime substance abuse or dependence (substance use disorder), oppositional defiant personality disorder, attention deficit hyperactivity disorder, bipolar disorder, conduct disorder, and habitual or concerning use of cannabis or any illicit drug was derived from prior mental health case records or current assessment by a licensed provider. All assessments and diagnoses were made using the DSM-IV and were assigned by licensed clinicians, which provided reliability and validity to these measures. The continuous variable age of first juvenile court involvement was the youth's age at first charged offense. Additionally, five different offense types were measured separately to account for youth with multiple offense types. The offense types included property crime, personal crime, drug crime, status offense, and court order violation. These took into account separate multiple offenses over time. This information was derived from official court records. One dependent variable, detention length, was measured for each youth in the study. Detention length was measured in days and included, for those juveniles placed into detention more than one time, an aggregate total over time.

\section{Data analysis}

Factor analysis was used to identify and condense variables which measure similar concepts. From the above list of variables, five factors were identified. 'Prior mental health history' (Chronbach's alpha $=.68$ ) includes the variables prior counseling, prior suicide attempt, prior hospitalization in a psychiatric hospital, and prior history of psychiatric medication. 'Abuse and neglect history' (Chronbach's alpha =.72) includes the variables history of neglect victimization, history of maternal substance abuse, history of paternal substance abuse, and history of child welfare involvement. 'Court Disposition (CD) mental health services' (Chronbach's alpha $=.61$ ) consists of the variables court disposition for counseling, court disposition for mental health evaluation, and court disposition for drug screening. 'Substance use and abuse' (Chronbach's alpha $=.65$ ) consists of the 
variables substance use, substance use disorder, and use of cannabis. 'Emotional and behavioral issues' (Chronbach's alpha $=.59$ ) consists of the variables oppositional defiant personality disorder, attention deficit hyperactivity disorder, bipolar disorder, and conduct disorder.

In order to evaluate the research question of interest, multiple linear regression was used. The 19 independent variables (youth's current age, age at first delinquency, race, gender, number of siblings, victim of physical abuse, victim of sexual abuse, court disposition to shelter care, court disposition to public children's service agency - PCSA, five separate offense types (property crime, personal crime, drug crime, status offense, and court order violation), and five extralegal factors - prior mental health history, neglect history, court disposition to mental health services, youth substance use and abuse, and emotional and behavioral issues) were regressed on the one dependent variable juvenile detention length.

\section{Results}

There were eight independent variables that had a statistically significant relationship to the number of days in detention, when controlling for all the other independent variables (see Table 1). By comparing the standardized regression coefficients (or Betas) an order of importance for these independent variables can be determined. The most important variable to explaining the number of days in detention was a court order violation offense $($ Beta $=0.30)$. Closely behind was the age at the first delinquency adjudication. This is a negative relationship, meaning the younger the youth at the first delinquency, the longer the number of days of detention. The other independent variables that were significant had relatively equal Beta values: court disposition relating to a mental health area; suffering from neglect or parental substance abuse; a prior mental health history; race (AfricanAmerican); having a personal crime offense; and being the victim of physical abuse. This model was statistically significant $(p<0.001)$, with an adjusted $R^{2}$ of 0.24 . This means that 24 percent of the variation in the number of days spent in detention can be explained by these independent variables.

\section{Discussion}

This study found eight independent variables were significant predictors of detention length. These variables have been previously linked with juvenile justice system involvement or placement in detention. Indeed, others have found early age of juvenile court involvement, minority race (Johnson, 2009; Puzzanchera, et al., 2008), neglect and/or physical abuse (Currie and Tekin, 2006; Egeland et al., 2002), parental substance abuse (Thornberry, Smith, Rivera, Huizinga, and Stouthamer-Loeber, 1999) mental health disorders (Mallett et al., 2009; Moffitt and Scott, 2008), and personal crime offenses (Mersky and Reynolds, 2007) to be predictive of later offending and delinquency, and some authors linked these predictors to incarceration or residential placement. These particular multivariate findings which predict length of detention are unique to this study (Loughran et al., 2009; Winokur et al., 2008). 
Table I. Regression of independent variables on days in detention

\begin{tabular}{lccrrl}
\hline Independent Variables & B & Std. Error & Beta & \multicolumn{1}{c}{ T } & Sig \\
\hline (Constant) & 55.45 & 34.41 & - & 1.61 & .11 \\
Race (African American) & 15.17 & 5.48 & .16 & 2.77 & .0 I $^{*}$ \\
Prior mental health history & -5.99 & 2.54 & -.16 & -2.36 & $.02^{*}$ \\
Neglect history & 6.77 & 2.33 & .19 & 2.91 & $.00^{*}$ \\
Court disposition mental health & 8.73 & 3.13 & .20 & 2.79 & $.0 I^{*}$ \\
Youth substance use and abuse & -.97 & 1.57 & -.05 & -.62 & .54 \\
Emotional/behavioral issues & -2.10 & 3.69 & -.04 & -.57 & .57 \\
Age on January I of data year & 1.28 & 2.16 & .04 & .59 & .56 \\
Number of siblings & -1.57 & 1.57 & -.06 & -1.00 & .32 \\
Age first delinquency adjudication & -6.28 & 2.23 & -.22 & -2.82 & .0 I $^{*}$ \\
Victim of physical abuse & 21.41 & 9.34 & .13 & 2.29 & $.02 *$ \\
Victim of sexual abuse & 7.76 & 12.75 & .04 & .61 & .54 \\
Court disposition to shelter care & -9.90 & 13.07 & -.05 & -.76 & .45 \\
Court disposition to PCSA & -11.59 & 18.06 & -.04 & -.64 & .52 \\
Offense: property crime & 1.53 & 5.43 & .02 & .28 & .78 \\
Offense: personal crime & 14.71 & 5.45 & .16 & 2.70 & $.01 *$ \\
Offense: drug crime & 6.98 & 6.82 & .07 & 1.03 & .31 \\
Offense: status offense & -1.42 & 5.61 & -.02 & -.25 & .80 \\
Offense: court order violation & 27.76 & 5.51 & .30 & 5.04 & $.00^{*}$ \\
\hline
\end{tabular}

*Significant at $p<.05$

Here, some youth for a variety of reasons experience extended detention. Legitimate predictors of longer detention length such as committing a personal crime (Beta $=.16)$ or violating a court order $($ Beta $=.30)$ were nearly as likely in this sample to predict detention length as other extra-legal predictors such as race $($ Beta $=.16)$, court disposition for mental health problems $($ Beta $=.20)$, child welfare involvement $($ Beta $=.19)$ and physical abuse victimization $($ Beta $=.13)$. Numerous factors that increase duration of detention are demographic or extra-legal experience related variables that these youth have prior to their first juvenile justice system contact: minority race, mental health issues, physical abuse, and neglect. It should also be noted that found here, and in most United States juvenile courts, there is an overrepresentation of serious offending among minority youth (Puzzanchera and Adams, 2008).

The relationships found in this study are consistent with previous research on detention placement, yet extend our knowledge. This study sample includes an over-representation of detained minority youth (72\%). Looking more closely at other issues, such as prior mental health history, physical abuse/neglect history, and age of first delinquency adjudication, that co-occur with racial disparities at the detention point in the system may be helpful to juvenile justice decision makers as they explain and resolve this problem. Ongoing investigations continue to try to explain these racial disparities, a complicated inquiry because of the multiple decision points in the juvenile justice process and the multiple possible factors and stakeholders involved.

Knowing that detention is expensive, increases recidivism, and decreases positive outcomes for youth (Benda and Tollet, 1999; Holman and Ziedenberg, 2006; Justice Policy Institute, 2009), it makes sense to focus on prevention initiatives which are cost effective and successful (American Bar Association, n.d.) and interventions designed to help youth 
understand the consequences of their behavior and learn skills to prevent future delinquency (Krisberg, Barry, and Sharrock, 2007; Roberts, 2004). Indeed, the impact of early intervention is seen in this study. Mental health counseling that occurred prior to juvenile court involvement was shown to decrease detention length.

These findings are also in line with more recent juvenile justice system reform efforts focused on juvenile offender rehabilitation and less reliance on institutionalization (Krisberg, and Sharrock, 2007; Youth Transitions Funders Group, 2005). These changes in the United States have been led by the Annie E. Casey Foundation's Juvenile Detention Alternatives Initiative (JDAI), a 15-year effort to assist juvenile courts in decreasing their use of detention, reduce racial disparities, and improve public safety (Annie E. Casey Foundation, 2010). JDAI works to collaborate across youth caring systems (child welfare, mental health, schools, for example), utilizes standardized assessment instruments and data collection within juvenile courts, and builds community-based rehabilitative alternatives. Results, depending on length of implementation, have been very positive in the over 100 communities in which the Initiative has been involved, lowering detention populations and reoffending, and decreasing racial disparities (Anne E. Casey Foundation, 2009; Mendel, R.2009).

Similarly, the International Juvenile Justice Observatory (IJJO) is in concordance in upholding the United Nation's rights of all children, but specifically endorses the prevention of juvenile delinquency through the coordination and cooperation of the youth's home, school, and community environments, in addition to working with the legislature, media, and juvenile courts. Also, the IJJO endorses the United Nation's minimum rules concerning non-custodial care for these youth through the greater utilization of community involvement as well as juvenile offender treatment and rehabilitation (International Juvenile Justice Observatory, 2010).

\section{Limitations/future research}

This study has some limitation of note. First, the sample utilized only represents youth from one county in the United States which limits external validity. Also, the variables measured relied on existing case records. The extent to which these files contain errors and omissions is unknown. For some variables this may be particularly salient, for example, substance use and prior suicide attempts may be under-reported. An additional limitation is the relatively small amount of variance explained by the model. This research has identified some statistically significant variables that predict detention length, but other important variables which predict detention length were not included in this study. Potentially explicative information or data was not available at earlier youth arrest, referral, or case petitioning decision points. Future research should continue this line of inquiry and should include the variables number of delinquency adjudications and number of prior offenses.

\section{Conclusion}

In this study of youth from one large, urban Midwestern county in the United States, the following variables were shown to predict longer detention length: African-American 
race; prior mental health service; court disposition in a mental health area; neglect; physical abuse; early age at first delinquency adjudication; personal crime offense; and court order violation. Given the distinct disadvantages these youth with longer detention lengths experience (abuse and neglect histories and mental health issues, among others) continued system change and ongoing detention reform is supported by these findings. Indeed, if the juvenile court studied here is to meet its goal of accountability and rehabilitation, implementing some thoughtfully designed diversion and intervention strategies is important, or better yet involvement with the Juvenile Detention Alternatives Initiative (Annie E. Casey Foundation, 2010). For these initiatives mirror internationally supported reform efforts, drawing upon non-custodial measures as possible alternatives, including, but not limited to, restitution, suspended sentences, non-institutional treatment, conditional discharge, or deferred sentences in coordination with treatment (United Nations, 1990).

This exploratory research is unique in that it demonstrated an association between certain legal and extra-legal variables and detention length. Although it was beyond the scope of this study, future research should include additional variables and investigate how youth attributes interact with the policies and detention making decisions within the juvenile courts.

\section{References}

American Bar Association (n.d.) Juvenile Justice: Facts and figures. Available at: http://www.abanet.org/ media/jjqa.html

American Psychiatric Association (2000) Diagnostic and Statistical Manual of Mental Disorders. IV: Text revisions. Washington, DC: American Psychiatric Association Press.

Annie E Casey Foundation (2009) Detention Reform: An effective approach to reduce racial and ethnic disparities in juvenile justice. Baltimore MD: The Annie E. Casey Foundation.

Annie E Casey Foundation (2010) Juvenile Detention Alternatives Initiative, Core Strategies. Available at: http://www.aecf.org/MajorInitiatives/JuvenileDetentionAlternativesInitiative/JDAIResults.aspx

Benda BB and Tollet CL (1999) A study of recidivism of serious and persistent offenders among adolescents. Journal of Criminal Justice 27(2): 111-126.

Budeiri P (1999) Secrecy Shrouds Decisions about Release of Juvenile Major Offenders: Far-reaching negative ramifications likely. Richmond, VA: Mental Health Association of Virginia Public Policy and Advocacy.

Currie J and Tekin E (2006) Does Child Abuse Cause Crime? Available at: http://aysps.gsu.edu/publications/2006/downloads/CurrieTekin_ChildAbuse.pdf

Davis A, Tsukida C, Marchionna S, and Krisberg B (2008) The Declining Number of Youth in Custody in the Juvenile Justice System. Oakland, CA: National Council on Crime and Delinquency. Available at: http:// www.nccd-crc.org/nccd/n_initmhjj_pubs.html

Egeland B, Yates T, Appleyard K, and van Dulmen M (2002) The long-term consequences of maltreatment in the early years: A developmental pathway model to antisocial behavior. Children's Services: Social Policy, Research, and Practice 5(4): 249-260.

Evans CC and Vander Stoep A (1997) Risk factors for juvenile justice system referral among children in a public mental health system. The Journal of Mental Health Administration 24: 443-455.

Fagan AA (2005) The relationship between adolescent physical abuse and criminal offending: Support for an enduring and generalized cycle of violence. Journal of Family Violence 20(5): 279-290.

Ford JD, Chapman JF, Hawke J, and Albert D (2007) Trauma among Youth in the Juvenile Justice System: Critical issues and new directions. Delmar, NY: National Center for Mental Health and Juvenile Justice. Available at www.ncmhjj.com 
Gatti U, Tremblay RE, and Vitaro F (2009) Iatrogenic effect of juvenile justice. Journal of Child Psychology and Psychiatry 50(8): 991-998.

Green AE, Gesten EL, Greenwald MA, and Salcedo O (2008) Predicting delinquency in adolescence and young adulthood. Youth Violence and Juvenile Justice 6(4): 323-342.

Green AE, Hoyt EH, Schiraldi V, Smith BB, and Ziedenberg J (2001) Pathways to Juvenile Detention Reform: Reducing racial disparities in juvenile detention. Baltimore, MA: The Annie E Casey Foundation.

Grisso T (2008) Adolescent offenders with mental disorders. The Future of Children 18(2): 143-162.

Hawkins JD, Herrenkohl TL, Farrington DP, Brewer D, Catalano RF, and Harachi TW (1998) A review of predictors of youth violence. In Loeber R and Farrington DP (eds) Serious and Violent Juvenile Offenders: Risk factors and successful interventions. Thousand Oaks, CA: Sage Publications, 106-146.

Hay C, Fortson E, Hollist D, Altheimer I, and Schaible L (2006) The impact of community disadvantage on the relationship between the family and juvenile crime. Journal of Research in Crime and Delinquency 43(4): 326-356.

Heilbrum K, Goldstein N, and Redding R (2005) Juvenile Delinquency: Prevention, assessment, and intervention. New York, NY: Oxford University Press.

Herrenkohl RC, Egolf BP, and Herrenkohl EC (1997) Preschool antecedents of adolescent assaultive behavior: A longitudinal study. American Journal of Orthopsychiatry 67: 422-432.

Hodge JP and Greenleaf RG (2005) An exploratory analysis of the detention decision-making process in one county juvenile department. Journal of Ethnicity in Criminal Justice 3(3): 23-47.

Holman B and Ziedenberg J (2006) The Dangers of Detention: The impact of incarcerating youth in detention and other secure congregate facilities. Baltimore, MD: Annie E Casey Foundation.

Howell JC (2003) Preventing and Reducing Juvenile Delinquency: A comprehensive framework. Thousand Oaks, CA: Sage Publications.

Howing PT, Wodarski JS, Kurtz PD, Gaudin JM, and Herbst EM (1990) Child abuse and delinquency: The empirical and theoretical links. Social Work 35: 244-249.

Hoyt EH, Schiraldi V, Smith BB, and Ziedenberg J (2001) Pathways to Juvenile Detention Reform: Reducing racial disparities in juvenile detention. Baltimore, MD: The Annie E Casey Foundation.

International Juvenile Justice Observatory (2010) Definition and Mission. Available at: http://www.ijjo.org/ plantilla.php?pag $=010200$

Johnson L (2009) Federal Commitment Offers Welcomed Support to Local Initiatives to Promote Racial and Ethnic Fairness. Available at: http://www.modelsforchange.net/index.html

Justice Policy Institute (2009) The Costs of Confinement: Why good juvenile justice policies make good fiscal sense. Washington, DC: Justice Policy Institute.

Kashani J, Jones M, Bumby K, and Thomas L (1999) Youth violence: Psychosocial risk factors, treatment, prevention, and recommendations. Journal of Emotional and Behavioral Disorders 7: 200-212.

Knoll C and Sickmund M (2010) Delinquency cases in juvenile court, 2007. Washington, DC: Office of Juvenile Justice and Delinquency Prevention, Office of Justice Programs, US Department of Justice.

Krisberg B, Barry G, and Sharrock E (2007) Reforming juvenile justice through comprehensive community planning. Oakland, CA: National Council on Crime and Delinquency.

Lemmon JH (1999) How child maltreatment affects dimensions of juvenile delinquency in a cohort of lowincome urban males. Justice Quarterly 16: 357-376.

Lemmon JH (2006) The effects of maltreatment recurrence and child welfare on dimensions of delinquency. Criminal Justice Review 31(1): 5-32.

Lipsey M and Wilson DB (1998) Effective interventions for serious juvenile offenders: A synthesis of research. In Loeber R and Farrington D (eds) Serious and Violent Juvenile Offenders: Risk factors and successful interventions. Thousand Oaks, CA: Sage Publishers.

Lipsey M, Wilson DB, and Cothern L (2000) Effective Intervention for Serious Juvenile Offenders. Washington, DC: Office of Juvenile Justice and Delinquency Prevention, Office of Justice Programs, US Department of Justice.

Loeber R and Dishion T (1983) Early predictors of male delinquency: A review. Psychological Bulletin 94(1): 68-99. 
Loeber R and Farrington DP (2001) The significance of child delinquency. In: Loeber R and Farrington DP (eds) Child Delinquents: Development, intervention, and service needs. Thousand Oaks, CA: Sage Publications, 1-22.

Loeber R and Keenan K (1994) Interaction between conduct disorder and its comorbid conditions: Effects of age and gender. Clinical Psychology Review 14(6): 497-523.

Loughran T, Mulvey EP, Schubert CA, Fagan J, Pizuero AR, and Losoya SH (2009) Estimating a doseresponse relationship between length of stay and future recidivism in serious juvenile offenders. Criminology 47(3): 699-740.

Maas C, Herrenkohl TI, and Sousa C (2008) Review of research on child maltreatment and violence in youth. Trauma, Violence, \& Abuse 9(1): 56-67.

Mallett C, Stoddard-Dare P, and Seck M (2009) Predicting juvenile delinquency: The nexus of child maltreatment, depression, and bipolar disorder. Criminal Behaviour and Mental Health 19(4): 235-246.

Mason MA and Gibbs JR (1992) Patterns of adolescent psychiatric hospitalization: Implications for social policy. American Journal of Orthopsychiatry 62: 447-457.

Mauer M and King RS (2007) Uneven Justice: State rates of incarceration by race and ethnicity. Washington, DC: The Sentencing Project.

Maxfield JG and Widom CS (1996) The cycle of violence: Revisited six years later. Archives of Pediatric and Adolescent Medicine 150: 390-395.

Mears D and Aron L (2003) Addressing the Needs of Youth with Disabilities in the Juvenile Justice System: The current state of knowledge. Washington, DC: Urban Institute, Justice Policy Center.

Melton GB and Pagliocca PM (1992) Treatment in the juvenile justice system: Directions for policy and practice. In: JJ Cocozza (ed.) Responding to the Mental Health Needs of Youth in the Juvenile Justice System. Seattle, WA: The National Coalition for the Mentally Ill in the Criminal Justice System, 107-139.

Mendel R (2009) Two Decades of JDAI: From demonstration project to national standard. Baltimore, MD: The Annie E. Casey Foundation.

Mersky JP and Reynolds AJ (2007) Child maltreatment and violent delinquency: Disentangling main effects and subgroup effects. Child Maltreatment 12(3): 246-258.

Moffitt T and Scott S (2008) Conduct disorders of childhood and adolescence (Chapter 35). In: Rutter M (ed.) Child Psychiatry. London: Wiley-Blackwell Publishers.

Myner J, Santman J, Cappelletty G, and Perlmutter B (1998) Variables related to recidivism among juvenile offenders. International Journal of Offender Therapy and Comparative Criminology 42: 65-80.

National Council on Crime and Delinquency (2007) And Justice for Some: Differential treatment of youth of color in the justice system. Available at: http://www.nccd-crc.org/nccd/pubs/2007jan_justice_for_some.pdf

O'Neill B (2002) Influences on detention decisions in the juvenile justice system. Juvenile and Family Court Journal 53: 47-58.

Poe-Yamagata E and Jones M (2000) And Justice for Some. Washington, DC: Building Blocks for Youth. Available at: http://www.buildingblocksforyouth.org/justiceforsome/

Preski S and Shelton D (2001) The role of contextual, child, and parent factors in predicting criminal outcomes in adolescence. Issues in Mental Health Nursing 22: 197-205.

Puzzanchera C and Adams B (2008) National Disproportionate Minority Contact Databook. Developed by the National Center for Juvenile Justice for the Office of Juvenile Justice and Delinquency Prevention. Available at: http://ojjdp.ncjrs.gov/ojstatbb/dmcdb/

Puzzanchera C, Adams B, and Snyder H (2008) An interpretation of the national DMC relative rate indices for juvenile justice system processing in 2005. National Disproportionate Minority Contact Databook. Prepared by the National Center for Juvenile Justice for the Office of Juvenile Justice and Delinquency Prevention. Available at: www.ojjdp.ncjrs.gov/ojstatbb/dmcd/

Roberts AR (2004) Juvenile Justice Sourcebook: Past, present, and future. New York, NY: Oxford University Press.

Robertson AA, Dill PL, Husain J, and Undesser C (2004) Prevalence of mental illness and substance abuse disorders among incarcerated juvenile offenders in Mississippi. Child Psychiatry and Human Development 35(1): 55-73. 
Rosenblatt JA, Rosenblatt A, and Biggs EE (2000) Criminal behavior and emotional disorder: Comparing youth served by the mental health and juvenile justice systems. Journal of Behavioral Health Services and Research 27: 227-237.

Royse D, Thyer B, Padgett D, and Logan T (2006) Program Evaluation: An introduction. Belmont, CA: Thompson Brooks/Cole.

Scott M, Snowden L, and Libby AM (2002) From mental health to juvenile justice: What factors predict this transition? Journal of Child and Family Studies 11(3): 299-311.

Shelton HO, Neelum A, and Augarten I (2008) Critical Condition: African-American youth in the justice system. Washington, DC: Campaign for Youth Justice. Available at: http://www.njjn.org/media/resources/ public/resource_852.pdf

Shufelt JL and Cocozza JJ (2006) Youth with Mental Health Disorders in the Juvenile Justice System: Results from a multi-state prevalence study. Delmar, NY: National Center for Mental Health and Juvenile Justice.

Sickmund M (2006) Juvenile Residential Facility Census, 2002: Selected findings. Juvenile Offenders and Victims National Report Series. Washington, DC: US Department of Justice, Office of Programs, Office of Juvenile Justice and Delinquency Prevention.

Sickmund M (2009) Delinquency Cases in Juvenile Court, 2005. Washington, DC: Office of Juvenile Justice and Delinquency Prevention, Office of Justice Programs, US Department of Justice.

Sickmund M, Sladky TJ, and Wang W (2004) Census of Juveniles in Residential Placement Databook. Available at: http://www.ojjdp.ncjrs.org/ojstatbb/cjrp/

Smith C and Thornberry TP (1995) The relationship between childhood maltreatment and adolescent involvement in delinquency. Criminology 33: 451-481.

Soler M, Shoenberg D, and Schindler M (2009) Juvenile justice: Lessons for a new era. Georgetown Journal on Poverty Law \& Policy, Volume XVI, Symposium Issue.

Spilsbury JC, Belliston L, Drotar D, Drinkard A, Kretschmar J, Creeden R, Flannery DJ, and Friedman S (2007) Clinically significant trauma symptoms and behavioral problems in a community-based sample of children exposed to domestic violence. Journal of Family Violence 22(6): 487-499.

Stahl AL, Puzzanchera C, Livsey S, Sladky A, Finnegan T, Tierney N, and Snyder H (2007) Juvenile Court Statistics, 2003-2004. Washington, DC: National Center for Juvenile Justice, Office of Juvenile Justice and Delinquency Prevention, US Department of Justice. Available at: http://www.ncjrs.gov/html/ ojjdp/218587/

Stouthamer-Loeber M, Wei E, Homish D, and Loeber R (2002) Which family and demographic factors are related to both maltreatment and persistent serious juvenile delinquency? Children's Services: Social Policy, Research, and Practice 5(4): 261-272.

Takeda Y (2000) Aggression in relation to childhood depression: A study of Japanese $3^{\text {rd }}-6^{\text {th }}$ graders. Japanese Journal of Developmental Psychology 11(1): 1-11.

Teplin L, Abram K, McClelland G, Dulcan M, and Mericle A (2002) Psychiatric disorders in youth in juvenile detention. Archives of General Psychiatry 59: 1133-1143.

Teplin L, Abram K, McClelland G, Mericle A, Dulcan M, and Washburn D (2006) Psychiatric disorders of youth in detention. Washington, DC: Office of Juvenile Justice and Delinquency Prevention, Juvenile Justice Bulletin, Office of Justice Programs, US Department of Justice. Available at: http://www.ncjrs. gov/pdffiles1/ojjdp/210331.pdf

Thornberry TP, Ireland TO, and Smith CA (2001) The importance of timing: The varying impact of childhood and adolescent maltreatment on multiple problem outcomes. Development and Psychopathology 13(4): 957-979.

Thornberry TP, Smith C, Rivera C, Huizinga D, and Stouthamer-Loeber M (1999) Family Disruption and Delinquency. Juvenile Justice Bulletin (September). Washington, DC: Office of Juvenile Justice and Delinquency Prevention, Office of Justice Programs, US Department of Justice.

Torres C and Ooyen MV (2002) Briefing Paper. New York, NY: Committee on Youth Services. Available at: http://webdocs.nyccouncil.info/attachments/56612.htm?CFID=1677675\&CFTOKEN=84562487 
Tremblay RE and LeMarquand D (2001) Individual risk and protective factors. In: Loeber R and Farrington DP (eds) Child Delinquents: Development, intervention, and service needs. Thousand Oaks, CA: Sage Publications, 137-164.

Turner M, Hartman J, Exum M, and Cullen F (2007) Examining the cumulative effects of protective factors: Resiliency among a national sample of high-risk youths. Journal of Offender Rehabilitation 46(1/2): 81-111.

United Nations (1990) United Nations standard minimum rules for non-custodial measures (The Tokyo rules). Available at: http://www2.ohchr.org/english/law/tokyorules.htm

Watts D and Wright L (1990) The relationships of alcohol, tobacco, marijuana, and other illegal drug use to delinquency among Mexican-American, black, and white adolescent males. Adolescence 25(97): 171-181.

Westendorp F, Brink KL, Roberson MK, and Ortiz LE (1986) Variables which differentiate placement of adolescents into juvenile justice or mental health systems. Adolescence 21: 23-37.

Widom DC and Maxfield MG (2001) Research in Brief: An update on the 'cycle of violence'. Washington, DC: Office of Justice Programs, National Institute of Justice, US Department of Justice.

Wiebush R, McNulty B, and Le T (2000) Implementation of the intensive community-based aftercare program, Bulletin. Washington, DC: Office of Juvenile Justice and Delinquency Prevention, Juvenile Justice Bulletin, Office of Justice Programs, US Department of Justice.

Winokur KP, Smith A, Bontrager SR, and Blankenship JL (2008) Juvenile recidivism and length of stay. Journal of Criminal Justice 36: 126-137.

Youth Transitions Funders Group, Blueprint for Juvenile Justice Reform, 2005. Chicago, IL: Youth Transitions Funders Group. Available at: http://www.ytfg.org/documents/Platform_Juvenile_Justice.pdf

Zingraff MT, Leiter J, Johnson MC, and Myers KA (1993) The mediating effect of good school performance on the maltreatment-delinquency relationship. Journal of Research on Crime and Delinquency 31: 62-91.

Post-print standardized by MSL Academic Endeavors, the imprint of the Michael Schwartz Library at Cleveland State University, 2014 